\title{
Ingoldian Fungi in Kigga Falls, Chikmagalur District, Karnataka.
}

\author{
Suresha, H. R, Krishnappa, M., Raju, G. H \\ Department of Applied Botany, Kuvempu University,Shankaraghatta-577451, Shimoga dist. Karnataka
}

\begin{abstract}
Fungi are the ubiquitous organism.The exist in diverse forms in a range of habitats, arboreal, freshwater, marine, subterranean and terrestrial. In fresh water we concentrated only Ingoldian fungi. The selected study sites of foam samples and decaying debris were collected in the same study area and kept for screening and incubation respectively. The conidia developing on decayingdebris were screened using microscope. The collected foam samples were revealed Ingoldian fungi. In this contribution of occurrence and abundance of Ingoldian fungi were enumerated. A total of 24 species were isolated twelve genera were identified.
\end{abstract}

Key words: Ingoldian fungi, decaying debris, Water bodies.

\section{Introduction}

At a distance of $15 \mathrm{Kms}$ from Sringeri\& $5 \mathrm{Kms}$ from Kigga, Kigga Falls (also known as Sirimane Falls) is a popular waterfall located in the deep forest of Western ghats with a height of about 40 feet, this waterfall is located in scenic surroundings with dense forest all around. The falls are wide and can accommodate more forest litter at the bottom.Anamorphic fungi inhabiting forest litter are characterized by wide adaptation abilities in different environments, but their species composition and ecology are still insufficiently known. The best-known and most studied are terrestrial, aquatic and aero-aquatic groups of Hyphomycetes (Ellis 1971, 1976; Matsushima 1975; Ingold 1975;Bärlocher 1992 et al.).During the studies of Hyphomycetes associated with forest litter in various terrestrial and freshwater ecosystems in mixed deciduous forests of central and southeast Lithuania in 1999-2004, five rare and interesting for their ecological adaptation patterns species were obtained both in terrestrial and aquatic habitats. Recorded species were mainly polytrophic and developed as saprobes on dead woody plant substrates. Till present time three reported here fungi species, Cladorrhinum foecundissimum, Lateriramulosauni-inflata and Tetraploasetifera were known exceptionally as terrestrial or soil-inhabiting (Matsushima 1971; Mouchacca, Gams 1993; Révay 1993), other two, Dwayaangam cornuta and Pyramidospora herculiformisas aquatic ( Descals, Webster 1982; Singh1976). Our observation indicated that they can grow, sporulate and actively decompose plant debris of forest litter both in moist terrestrial and submerged conditions.This has focused attention on how and to what extent ecosystem functioning may be affected by changes in biological communities. Several hypotheses have been proposed concerning the relationship between biodiversity and ecosystem functioning (Johnson et al. 1996). MacArthur (1955) predicted a positive, linear relationship between species numbers and both productivity and the ability of ecosystems to recover from disturbances. The Ingoldian fungi most commonly occur on dead leaves (Webster and Descals 1981; Baerlocher 1992) and wood (Willioughby and Archer 1973; Sanders and Anderson 1979; Shearer and Webster 1981) as well as in foam (Iqbal and Webster 1973; Iqbal 1995). A few species have also been reported from well aerated and they mediate energy flow and nutrient cycling in streams ( Baldy et al., 1995) and act as intermediaries of energy flow between leaf litter and invertebrates (Baerlocher and Kendrict 1976; Suberkropp 1992). Relationship where species loss has a slight negative effect on ecosystem functions until a critical diversity level, beyond which further losses will seriously compromise ecosystem integrity. Similarly, the hypothesis (Walker 1992) predicts a positive and asymptotic relationship, where the loss of species is of little consequence as long as all functional groups arewell represented. Finally, the idiosyncratic hypothesis (Lawton 1994) assumes that the relationship between species richness and ecosystem functioning does not follow a consistent pattern, but depends crucially on the identity of species and on the order in which they are lost from ecosystems. There is no agreement as to which of these hypotheses best describes the relationship between biodiversity and ecosystem functions, but generally diversity has been positively associated with primary productivity or plant biomass (Naemet al).Fungi are instrumental in leaf decomposition in streams (Gessner \& Chauvet 1994), and their biomass accumulating on leaves improves substrate palatability and nutritional value to shredders (Barlocher 1985; Suberkropp 1992; Graca 2001). Positive interactions predominate (e.g., facilitation among freshwater invertebrates, Cardinale et al. 2002; There is no agreement as to which of these hypotheses best describes the relationship between biodiversity and ecosystem functions, but generally diversity has been positively associated with primary productivity or plant biomass 1999). In a community of species with complementary niches, positive interactions predominate (e.g., facilitation among freshwater invertebrates, Cardinale et al. 2002; and combination of facilitation and niche differentiation among grassland producers, 
Loreau and Hector 2001), leading to a greater overall efficiency of resource use. This raises community performance above the level expected from the sum of performances by individual species. On the other hand, the probability of encountering dominant species, which tend to be the most productive species, will increase with the number of species present in a community (sampling effect, Huston 1997; Tilman et al. 1997). The performance of a diverse community will therefore largely be determined by the inclusion of the species with the highest performance in monoculture (Huston 1997; Tilman et al. 1997). It is often difficult to distinguish between complementarity and sampling effects, and they may occur simultaneously, but if sampling effects predominate, the performance of multicultural asymptotically approaches an upper limit defined by the top performing monoculture.Their diversity has been correlated with temperature, water chemistry and quality of riparian vegetation (Baerlocher, 1987; Gonczol, 1987). Hypomycetesare group of aquatic community which degrades leaves and twigs shed in to water (Kaushik \& Hynes, 1971).In the present study, work was carried out on the colonization of aquatic fungi on the specific composition of foam, leaf debris and sporulation.

\section{Study area}

Kigga falls comes under district of chikmagalur the south Western parts of Karnataka state in India, situated at $13^{\circ} 19^{\prime} 31.99^{\prime \prime} \mathrm{N}$ latitude and $75^{\circ} 14^{\prime} 17.92^{\prime \prime} \mathrm{E}$ lonlgitude, the altitude of is $2517 \mathrm{ft}$. The temperature varies from $15^{\circ}$ to $25^{\circ} \mathrm{C}$ and the annual rain fall is $1904 \mathrm{~mm}$. The heavy rain fall has resulted in many water tanks, streams and reservoirs. A lot of foam is developed in all the seasons.The heavy rain fall has resulted in many water tanks, streams and reservoirs. Foam developed in all the seasons. Four study sites (A, B, C and D) were identified at Kigga falls stream, each site was sub divided into 2 sub sites (A1, A2, B1, B2, C1, C2, D1 and D2).

\section{Foam analysis}

\section{Materials and Methods}

The foam was scooped with the help of spoon and transferred into a jam jar or similar receptacle. Equal parts of FAA (Formal-acetic-alcohol) was added and fixed. The germined conidia were examined under microscope.

\section{Incubation studies}

During the investigation, water samples were collected from Kiggs falls of Chikmagalur District. Water samples were collected in small plastic bottles and leaf debris were collected in sterile polythene bags. The substrate of plant leaves and wood pieces were also kept for incubation. Fungi were isolated by a plating technique to separate different forms. When monocultures were growing, they were further studied for their colony characteristics. These fungi were further mass multiplied by the help of a baiting technique and were stored in sterile polyethythene bags.

The spores were identified under a compound microscope with great accuracy such that relatively small spores down to $5 \mathrm{~mm}$ in span or less could be isolated. Most Ingoldian fungi were isolated by the England finder technique as it offers several important advantages over the spore suspension technique. The slide finder is a standard sized microscopic slide bearing a photographically reduced grid pattern. Each compartment on the grid is identified with letter or number coordinates arranged sequentially along the horizontal and vertical axes. A piece of agar medium from an incubation plate was placed on the finder, the coordinates directly underneath each spore were noted and any spores detected were relocated individually under the compound microscope.

\section{Isolation of suspended spores}

The hair technique was used to capture single spores in isolation under the dissecting microscope. The incubated plates were placed under the dissecting microscope then spore along with leaf bits. The conidial expression was observed, after confirming the conidia with the help of mounted hair, single conidia were transferred to malt extract plates. The plates were incubated at $18^{\circ} \mathrm{C}$ for one week. The micropipette technique was used to capture floating spores in incubated plates. The incubated plates were placed under the dissecting microscope and the conidia were observed. The selected spores were sucked into a micropipette and directly transferred to the malt extract plate. The plates were incubated at $18^{\circ} \mathrm{C}$ for one week. 
Table.1. Occurrence and distribution of Ingoldian fungi in Kigga falls.

\begin{tabular}{|c|c|c|c|c|c|c|c|c|c|}
\hline & & & & & & & & & \\
\hline $\begin{array}{l}\text { Sl. } \\
\text { No. }\end{array}$ & Species Name & A1 & A2 & B1 & B2 & C1 & $\mathrm{C2}$ & D1 & D2 \\
\hline 1 & Anguilosporacrassa & + & - & + & - & + & - & - & + \\
\hline 2 & Centrosporaaquatica & + & - & - & + & - & + & - & - \\
\hline 3 & Centrosporaaccurina & + & - & + & + & - & - & - & + \\
\hline 4 & Limnoriaangulata & + & - & - & + & + & - & + & - \\
\hline 5 & Dactylellaacuminata & + & - & - & - & - & - & - & - \\
\hline 6 & Tricelosporausmanosporas & + & + & + & + & + & + & + & + \\
\hline 7 & Tricelosporusaccuminatus & + & - & - & + & - & + & - & - \\
\hline 8 & Lunulosporacurvala & + & - & + & - & + & - & + & - \\
\hline 09 & Tetrachaetumelegans & + & + & + & + & + & + & + & - \\
\hline 10 & T.angulatum & + & + & + & + & + & + & + & + \\
\hline 11 & T.furcatum & + & + & + & + & + & + & + & - \\
\hline 12 & Clucidosporagravida & + & + & + & - & + & - & + & - \\
\hline 13 & Alatosporapulchella & - & - & + & - & + & - & + & - \\
\hline 14 & Lunulosporacurvala & + & - & + & + & - & - & - & - \\
\hline 15 & Anoptederamangrove & - & + & - & - & - & - & - & - \\
\hline 16 & Lemoneriaterrestris & + & - & - & + & + & - & + & - \\
\hline 17 & Clucidosporaaquatica & - & - & - & - & - & + & + & - \\
\hline 18 & Tetracladiummarchalianum & - & - & + & - & + & + & + & - \\
\hline 19 & Anopderaindica & - & - & - & + & + & - & - & - \\
\hline 20 & Anguilosporalongissima & - & - & - & - & + & + & - & - \\
\hline 21 & Anguilosporagigntia & - & - & + & + & + & - & - & - \\
\hline 22 & Limonoriapseudofloscula & - & - & - & + & - & - & + & + \\
\hline 23 & Actinosporamegalospora & - & - & - & + & - & - & - & - \\
\hline 24 & Flabellosporacrassa & + & + & - & - & - & - & + & - \\
\hline
\end{tabular}

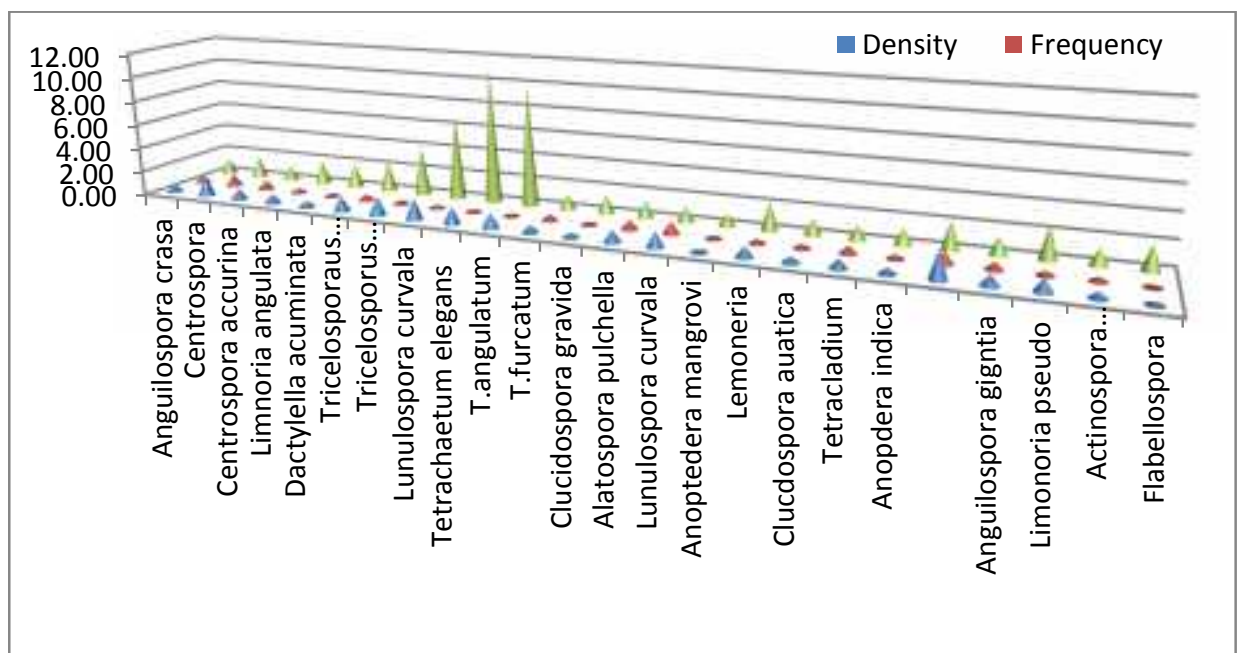

Fig. 1.Occurrence of Ingoldian fungi among different genera in a selected study site

\section{Results}

In the present study accounts 24 species (Table-1) of Ingoldian fungi belonging to twelve genera were isolated from the foam samples\&debris of study sites. Environmental factors which influence the diversity of aquatic hyphomycetes, T,anguilatum, T,farcatum and. Tetrachaetumelegansare the common in all the study sites (Fig-1) shows clearly graphical representation. Dactylella acuminate, Actinosporamegalospora \& Anoptedera mangrove are very rare species in this study area.

\section{Discussion and conclusion}

The Ingoldian fungi play important role in degradation of organic complex to simpler form. The species of hyphomycetes occurs abundantly in submerged leaves. The study proved that different Ingoldian species vary in their susceptible to soluble substance present in plant materials. In this study area contains rich 
vegetation hence varies tree species is commonly found in this study area. The tree species produces variety of dead leaves and are collected in aquatic ecosystem. The rain fall is very high in compare to other taluks rain fall create aquatic ecosystems. The diversity of aquatic fungi rich in this study area compares the other study sites.

Producers, such as plants and algae, acquire nutrients from inorganic sources that are supplied primarily by decomposers whereas decomposers, mostly fungi and bacteria acquire carbon from organic sources that are supplied primarily by producers.In the present study accounts twenty four species (Table-1) of aquatic fungi belonging to twelve genera were isolated from the foam samples of study sites. In kigga falls maximum numbers of Ingoldian fungi Dactylella acuminate, Actinospora megalospora \& Anoptedera mangrove were recordedout of eight study sitesandare very rare species recorded only in one study site whereas, T,anguilatum, T,farcatumsp and Tetrachaetum elegans were recorded in eight study sites (Fig-1) shows clearly in graphical representation.The freshwater ecosystemwhere fungi have been studied in particularly plant litter decomposition subsystem, they have been found to play key role both in the cycling of carbon and nitrogen and in mediating energy flow to higher levels. Fungi undoubtedly have a number of other roles in these ecosystems.

\section{Acknowledgement}

The first author is very thankful to department of Applied Botany, Kuvempu University for providing the laboratory facilities.

\section{References}

[1]. Barlocher F:Aquatic hyphomycetespora in 10 strems of New Brunswick and nova scotia.Canadian journal of Botany 65:76-79.1X

[2]. Barlocher, F. 1992. Community organization. The ecology of aquatic hyphomycetes, Springer-Verlag, Berlin, 38-76.

[3]. Barlocher, F., Schweizer, M. 1983. Effect of leaf size and decay rate on colonization by aquatic hyphomycetes. Oikos. 41: 205-210.

[4]. Barlocher,F.(1992)Effect of drying and freezing autumn leaves on leaching and colonization by aquatic hypomycetes. Fresh water biollogy28:1-7.1X

[5]. El-Hissy, F.T., Rouf, A. and Khallil, M. 1990. Fungi associated with some aquatic plants collected from fresh water areas at assuit (Upper Egypt). Journal of Islamic Academy of Sciences. 13: 298-304.

[6]. Ellis,M.B. 1971:Dematiaceoushypomycetes.Commonwealthmycological institute, Kew, 608pp. figs.48.51,180.T+1X PARTIAL.

[7]. Griffith, M.B. and S.A. Perry. Fungal biomass and leaf litter processing in streams of different water chemistry. Hydrobiology. 294: 51-61.

[8]. Guilis K. Suberkropp. 2003. Effect of inorganic nutrients on relative contributions of fungi and bacteria to carbon flow from submerged decomposing leaf litter. Microbe. Ecol.45: 11-19.

[9]. Kaushik,N.K. and Hynes,H.B.N.(1971):The fate of the dead leaves that fall in to streams.Archiv fur Hydrobiologie68:465-515.ix

[10]. Ingold, C.T.1975 Conidia in the foam of two English streams. Transactions of the British mycological society65:522-527.Textfig.1-4.1X

[11]. Kaushik,N.K.\&Hynes,H.B.N.(1971):The fate of the dead leaves that falls in to streams. Archiv fur hydrobiologia68:465-515.1X

[12]. Koske,R.E.\&Ducan,I.W.(1974) : Temperature effects on growth,sporulation and germination of aquaatichypomycetes. Canadian journal of botany52:1387-1391.Figs.1-12.1X

[13]. Gonczol,j.(1987):Ecological observation on the aquatic hyphomycetes of Hungary.111,Acta Botanical Hungarica 33:41-49.1x

[14]. Leano, E.M. 2001. Straminipilous organisms from fallen man grove leaves from Panay Island, Philippines. Fungal Diversity.6: 75 81.

[15]. Mathsushima,T.(1971b):Microfungi of the Solomon Islands and papua, New Guinea.Mathsushima,kube,78pp.

[16]. Descals,E.\&Webster,j.(1982):Taxonomic studies on Aquatic hyphomycetes.111.Somenewspecies and a new combination.Transactions of the British mycological society 78:405-437.figs 1-38.1x

[17]. Gessner\&Chauvet,E.(1994):Impertance of stream microfungi in controlling breakdown rates of leaf litter Ecology75:1807-1817.IR

[18]. Suberkropp, K. 1991. Relationships between growth and sporulation of aquatic hyphomycetes on decomposing leaf litter. Mycol. Res.95: 843-850

[19]. Suberkropp, K. 1995. The influence of nutrients on fungal growth, productivity and sporulation during leaf break down in streams. Can. J. Bot.73(Suppl.1): S1361-S1369.

[20]. Willoughby,L.G.\&Archer,J.F.(1973):The fungal spora of a freshwater stream and its colonization pattern on wood.freshwater biology 3:219-239.Fig.1-9.IR 